\title{
Tubulin Beta-3 Chain
}

National Cancer Institute

\section{Source}

National Cancer Institute. Tubulin Beta-3 Chain. NCI Thesaurus. Code C104244.

Tubulin beta-3 chain (450 aa, $\sim 50 \mathrm{kDa}$ ) is encoded by the human TUBB3 gene. This protein is involved in both axonal guidance and microtubule structure. 